Vol-VI, Issue-02, (July-December, 2011) \& Vol-VII, Issue-1 (January-June, 2012)

\title{
Determinants of Self-esteem and Social Responsibility among Undergraduates of Dhaka City: Effects of Gender, Family Pattern and University Type
}

\author{
SHAYAMA AKHTER ${ }^{*}$ \\ MD. SHAKHAWAT HOSSAIN ${ }^{* *}$
}

\begin{abstract}
This paper is based on the results of a conducted study to investigate the level of self-esteem and social responsibility of the students of Bangladesh by the types of university, gender and family pattern. The sample of the study consists of 120 students where 60 students are from a public university and the remaining 60 students from a private university. In both cases, the 60 students are drawn as 30 male and 30 female. Of these two genders, 15 are from nuclear families and the other 15 from joint families. Therefore, there are total four levels of the public and private university students. The data are collected through questionnaires and analyzed by the analysis of variance. Results have revealed that self-esteem and social responsibility are significantly different according to the types of family pattern and gender while self-esteem differs by the types of university but social responsibility does not.
\end{abstract}

Key Words: Self-esteem, Social responsibility, Gender, Family pattern, University type.

\section{INTRODUCTION}

Although higher education attainment in Bangladesh is very low, each year a number of students get themselves enrolled on many courses of different public and private universities where the majority students are interested in studying at the universities located in Dhaka city. As there is an increased demand for higher studies among people, a large number of private universities have emerged in Bangladesh. According to Bangladesh Bureau of Educational Information and Statistics (BANBEIS, 2006), there are 27 public and 54 private universities in Bangladesh. The enrollment of students in these public and private universities is

\footnotetext{
*Senior Lecturer in Psychology, Department of Business Administration, Northern University Bangladesh (NUB), Dhaka.

"Lecturer in English, Department of English, Northern University Bangladesh (NUB), Dhaka.
} 
increasing gradually because of the fastest-growing population and a comparatively higher success rate in the higher secondary level of education. As the public universities of Bangladesh cannot create opportunities for the mass population, a number of students go to the private universities in order to fulfill their aspiration for higher education.

Besides, some students like to enroll on many market oriented disciplines which the public universities either do not offer or lack in seats. It is seen that the students, who are from both nuclear and joint families, are enthusiastic to study at the universities located in Dhaka city because of its unique features.

The public universities offer a variety of disciplines including both general and market oriented but due to the scarcity of seats, a number of students fail to secure a position in the merit list although they possess sound merits. As the public universities lack in adequate seats on demandable disciplines, students have to go to the private universities where education is attained at the cost of money. Moreover, the private universities only offer a few popular and marketoriented disciplines like business administration, computer science, engineering and medicine because after having a degree on one of these disciplines, one can secure a good job in the competitive job market. Furthermore, many students do not get interest in enrolling at the public universities as there is evil student politics and session jams. On the other hand, the students who enroll themselves at different public universities may be boastful of their position while others may suffer from the inferiority complex. Hence, such feelings of superiority and inferiority influence the personal development of an individual which is reflected through the participation of the students in various kinds of social activities. It has been observed that the university students of Bangladesh participate in different social activities e.g. fund-raising for the flood or cyclone affected people, consciousness raising campaign against female oppression and for basic human rights. Such kind of participation represents the consciousness of our graduates. As the undergraduate students of a country are the major source of future leadership, it is very important to know what and how they think of themselves and what level of self-esteem do they possess and how do they perform their social responsibilities. Therefore, the present study has given much concentration on the undergraduate students of Dhaka city in order to identify the level of self-esteem and social responsibility with effects of gender and family pattern. The objectives of the study are as follows:

i) To determine the level of self-esteem and social responsibility of the undergraduates of public and private universities in Dhaka city

ii) To determine the level of self-esteem that differs due to different genders and family patterns 
iii) To determine the level of social responsibility with the variables of gender and family pattern

Self-esteem is a widely used concept of psychology. It refers to an individual's sense of his or her value or worth, or the extent to which a person values, approves of, appreciates, prizes, or likes him or herself (Blascovich and Tomaka, 1991). The most broad and frequently cited definition of self-esteem within psychology is Rosenberg (1965), who described it as a favorable or unfavourable attitude towards the self.

Self-esteem is generally considered as an evaluative component of selfconcept that includes cognitive and behavioral aspects as well as evaluative or affective ones (Blascovich and Tomaka, 1991). It is also widely assumed that self-esteem functions as a trait which is relatively stable over time within individuals. Self-esteem is an extremely popular construct within psychology, and has been virtually related to every other psychological concept or domain, including personality (e.g. shyness), behavioral (e.g. task performance), cognitive (e.g. attribution bias), and clinical concepts (e.g. anxiety and depression).

On the other hand, the concept of social responsibility is an old but important issue in social psychology. Social responsibility refers to a tendency to help others without expecting any immediate personal reward (Berkowitz and Daniel, 1976). It is mainly concerned with the questions of ethics and morality (Kelley and Byrne, 1976).

\section{LITERATURE REVIEW}

Correlation studies suggest that family plays an important role in the child's self-esteem. Children with positive self-esteem come from homes in which parents exercise control in a democratic yet non-permissive manner; communicate with their children and encourage their children to display affection and other emotions (Wylie, 1961; Coppersmith, 1967; Damon, 1983). These same parenting techniques also seem to result in having children who are independent, self-assertive and competent. Some other correlation studies have also showed that children tend to evaluate themselves in part on the basis of how they believe their parents evaluate them (Felson, 1989). Parental attitudes and behaviour-acceptance of their children, clear and well-enforced demands and respect for their actions within well-defined limits are the primary antecedents of children's sense of self-worth (Pervin, 1993).

In addition, family structure, family functioning and adolescent well-being are also related to the development of children's self-esteem. Quite a number of studies are done on these issues. Results from these studies have indicated that 
the configuration of the family is the key determinant of effectiveness of family functioning. Instead, the style of parenting has turned out to be the main determinant of both families (joint and nuclear) and well being of the adolescents. While both 'parents' were judged to have contributed to these outcomes cross gender effects were found to be important. (Allan, Anthony and Geoffrey, 2003).

Self-esteem originates early in life and the structure becomes increasingly elaborate over the childhood and adolescent years. Children (generally in their pre-school and school years) develop an array of separate self-esteem first; later integrate them into an overall impression (Harter, 1990). With the arrival of adolescence, several other new dimensions of self-esteem are added that reflect concerns of their pride. Adolescence period has been viewed as filled with stress and uncertainty about self which riddle with sudden and frequent mood shifts. During these years their thoughts and behaviour are often devoted to exploring alternatives before commitment to a course of action with respect to social relationships, vocational and life style what is greatly influenced by peer groups (Marcia, 1980).

In fact, no one on the earth is created with the absolute perfection as everyone has some fields of strengths and limitations which are supposed to be acknowledged. There are some aspects of our behavior and appearance we may seek to change or develop, but a sense of self is developed from the selfawareness and self-acceptance. It is observed that a particular family's norms and values are echoed in the children's attitudes which help them to be accepted or recognized in the society. In the twenty-first century, families of all types (joint or nuclear) are recognized as the primary sources that model the children's selfesteem and social responsibility. Children are welcomed into the world by parents who esteem themselves and support their children's natural tendencies towards becoming constructive, responsible and trustworthy. Children are nurtured by their parents in such a way that all become healthy individuals who have a sense of identity and an awareness of own and potential. Families provide every member with healthy, stimulating, informative and growth-producing experiences.

Self-esteem is also related to socio-economic status, age, sex, father's education and income and achievement variables. Rosenberg and Pearlin (1978), for example, have found virtually no association between social class of parents and self-esteem among younger children, a modest association among adolescents, and a moderate association among adults based on their own social class. Richman et al., (1985) has found a main effect for the relationship between self-esteem and SEs among adolescents, but demonstrated complicated 
interactions of sex, race, and social class: white females (including high SEs individuals) are significantly lower in general self-esteem than white and black males and females. Wiltfang and Scarbecz (1990) have found that fathers' education has a small positive relationship with the adolescents' self-esteem and that adolescent achievement variables (school grades, group leadership, report of many close friends) have contributed more significantly to their self-esteem than the parental social class variables. Trzesniewski et al., (2003) has found in his studies that self-esteem stability is low during childhood, increases throughout adolescence and young adulthood and declines during midlife and old age. High self-esteem individuals (High SEs) differ from their low self-esteem counterparts (Low SEs) in the way they think and act, the way they behave in organization. People with high self-esteem will generally be willing to take the risk of admitting when they are wrong which can contribute considerably to their persuasiveness. People with low self-esteem may be less communicative than those with high self-esteem. The most generalized finding on self-esteem is that low self-esteem individuals are more susceptible to external influence than high self-esteem individuals (Robbins, 1990).

Social responsibility is voluntary; it is about going above and beyond what is called for by the law (legal responsibility). It involves an idea that it is better to be proactive rather than reactive to a problem. Social responsibility means eliminating corruption, irresponsibility or unethical behavior that might bring harm to the community, its people, or the environment before the behavior happens. So social responsibility covers a number of areas that include - human responsibility, environmental responsibility etc.

Social responsibility is associated with individual character as well as many situational variables. It has been found that responsible students are actively involved in community affairs (Berkowitz and Lutterman, 1968). Jahan and Sarkar (1995) have investigated the socially responsible behavior of urban and rural distressed people of Bangladesh and found that the urban poor are significantly more socially responsible than the rural community where Khanam and Begum (1997) have identified that middle class women have greater social responsibility than that of higher and lower classes.

In a study of early adolescents $(\mathrm{N}=606)$, representation of relationships with teachers, parents and friends are examined in relation with each other and to various measures of social responsibility, motivation and self- esteem (Feinberg, E.M., Neiderhiser, M.J. 2000); and the findings are discussed in terms of the significance of relatedness for motivation generally and the importance of the affective quality of adult-student relationships for educational outcomes in particular. 
From the literature reviewed above, it has become clear that self-esteem and social responsibility are the functions of families and teachers (e.g. the guidance of parents at home and teachers at the educational institutions) and the peers of a human child. Out of the three sets of people i.e. parents, teachers and friends, the present article has attempted to verify empirically the relationship between selfesteem or social responsibility (as dependent variable) and parents (i.e. family type) and teachers and peers (i.e. represented by the educational institution type) as explanatory variables.

FIGURE 1: Schema showing Relationship between Better Self-esteem and Effective Social Responsibility with Parental care, Teachers' Guidance and Peers' Factor

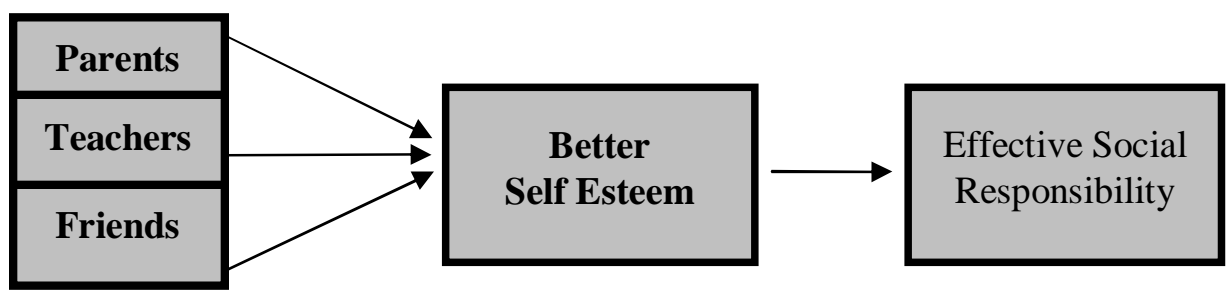

\section{METHODOLOGY}

The article is based on a primary survey in which data are collected from 120 undergraduate students of two universities of Dhaka city. The two universities, one is a public university and the other a private one, are randomly chosen. From each of the universities, 60 students ( 30 male +30 female) are randomly selected irrespective of their disciplines (areas) of studies. No details data on their parental socio-economic status (SES) are collected. Broadly, it is known that their parents' educational qualification ranges between the levels of SSC (Secondary School Certificate) and Master's ( $2^{\text {nd }}$ degree). The important explanatory (students') variables on which data are collected are on his/her family (whether nuclear or joint family type) and about his/her university type (whether it is public or private).

The two key (dependent) variables are self-esteem $\left(\mathrm{Y}_{1}\right)$ and social responsibility $\left(\mathrm{Y}_{2}\right)$ - the question is how they are defined and analyzed here for the study. In this article, the Bangla version (Ilyas, 2003) of Roserberg's selfesteem scale (1965) is used.

The scale was originally developed to measure adolescents' feelings of selfworth or self-acceptance. It is a 10-item Likert type scale in Bangla. The items are answered on a four point response format (strongly agree, agree, disagree, strongly disagree). The scale ranges from 10-40 with higher score representing 
lower-higher self-esteem. Five items estimate positive feelings and the other five items estimate negative feelings about self.

The scale is highly reliable: test-retest correlations are typically in the range of 0.82 to 0.88 and Cronbach`s alpha for various samples are in the range of 0.77 to 0.88 (Blascovich \& Tomaka, 1991). Significant correlation of English and Bangla versions $(r=0.87, \mathrm{p}<0.0005)$ indicates translation reliability of the Bangla version of the scale (Ilyas, 2003). High Cronbach's alpha $(\alpha=0.87)$ of the Bangla version further indicates internal consistency of the scale (Ilyas, 2003).

The second key (dependent) variable i.e. social responsibility $\left(\mathrm{Y}_{2}\right)$ utilized here is the Bangla version (Huq et.al, 1984) of Berkowitz and Lutterman scale of social responsibility. The scale contains eight items. For each of the eight items the respondent ranging from "strongly agree" to "strongly disagree". The statements are so constructed that for some responsibility is indicated by agreement and for others it is indicated by disagreement. For those items where agreement is the index of responsibility, scale value increases in the direction of agreement while for the items where disagreement is the indicator of responsibility, the scale value increases in the reverse direction. The sum of the values of all the scale points marked by a respondent constitutes the social responsibility score. The higher score is 40 and the lower value is 8 . Higher score indicates greater social responsibility.

The reliability of the Bengali version of the scale is tested by administering both English and Bengali versions of the scale on a group of Dhaka University students $(\mathrm{N}=50)$ with an interval of three weeks. Product moment correlation coefficient between the scales is 54 .

The study is done following a factorial design of $2 \times 2 \times 2$ representing gender (i.e. male and female), family-type (i.e. two levels of nuclear and joint) and university-type (i.e. public and private).

The procedure to implement the survey is as follows:

All of the 120 respondents of public (60) and private (60) universities are provided with printed questionnaires along with the instructions as to how they should work. Besides, they are made to understand the sequence of actions to complete the study. These instruments are administered individually to the mementos of the sample. The respondents are told that the sole purpose of the investigation is academic and their responses would be kept confidential. Prior to answering the questions, the respondents are asked to make a silent reading of the standard instructions that is provided with the scales. Subjects are asked to choose the most appropriate one and tick that. All necessary clarifications are 
made regarding the items. There is no time limit for answering. Therefore, they get enough time to answer the questions after having deliberate thought. The respondents are requested to record their demographic information (name of the student, sex, age, level of the study, father's education, mother's education, father's occupation, mother's occupation and so on. The total environment of data-collection, questionnaire-administration has been made very congenial to get maximum output. After collecting the data, the respondents are given thanks.

\section{RESULTS AND DISCUSSIONS}

In order to find out whether self-esteem and social responsibility vary as a function of gender, family pattern and university type, the scores are analyzed by the analysis of variation. The mean, standard deviation and coefficient of variation of self-esteem and social responsibility scores of respondents are shown in Table 1 and the results of ANOVA are shown in Table 2 and Table 3.

TABLE 1

MEAN, STANDARD DEVIATION (SD) AND CO-EFFICIENT OF VARIATION OF SELF-ESTEEM AND SOCIAL RESPONSIBILITY BY GENDER, FAMILY PATTERN AND UNIVERSITY TYPE

\begin{tabular}{l|l|c|c|c}
\hline \multicolumn{1}{c|}{ Determinants } & \multicolumn{1}{c|}{ Aspects } & Mean & SD & $\begin{array}{c}\text { Co-efficient } \\
\text { of Variation } \\
(\mathrm{CV})\end{array}$ \\
\hline 1. By Gender $\left(\mathbf{X}_{\mathbf{1}}\right)$ & & & & 0142 \\
a. Male & Self-esteem & 25.983 & 3.685 & 0.151 \\
b. Female & Social Responsibility & 28.967 & 4.365 & 0.153 \\
& Self-esteem & 26.083 & 3.98 & 0.158 \\
2. By Family Pattern $\left(\mathbf{X}_{\mathbf{2}}\right)$ & Self-esteem & 29.733 & 4.712 & 0.146 \\
a. Nuclear & Social Responsibility & 25.87 & 3.757 & 0.154 \\
b. Joint & Self-esteem & 29.03 & 4.464 & 0.149 \\
& Social Responsibility & 26.20 & 3.90 & 0.156 \\
3. By University Type $\left(\mathbf{X}_{3}\right)$ & Self-esteem & 29.67 & 4.627 & 0.143 \\
a. Public & Social Responsibility & 29.30 & 3.865 & 0.155 \\
b. Private & Self-esteem & 25.00 & 3.507 & 0.140 \\
\hline
\end{tabular}


From the table given above we have had three different types of results for the three different determinants. First, it is revealed that the female undergraduates possess better self-esteem $($ Mean $=26.08)$ and social responsibility (Mean $=29.73$ ) than the male ones who have scored (Mean $=25.98$ ) and (Mean $=28.96$ ) for self-esteem and social responsibility respectively. Secondly, the undergraduates of joint families have better self-esteem and social responsibility than them of joint families. Thirdly, the students of public universities hold healthier self-esteem than that of the private ones while the private university students possess better social responsibility than the public ones.

\section{TABLE 2}

\section{UNDERGRADUATES OF THE UNIVERSITIES IN DHAKA : SUMMARY OF ANOVA OF SELF-ESTEEM (DEPENDANT VARIABLE) BY GENDER, FAMILY PATTERN AND UNIVERSITY TYPE (AS EXPLANATORY VARIABLES)}

\begin{tabular}{|c|c|c|c|c|}
\hline Source & $\begin{array}{l}\text { Sum of } \\
\text { Squares }\end{array}$ & $\begin{array}{l}\text { Degrees of } \\
\text { Freedom }\end{array}$ & $\begin{array}{l}\text { Mean } \\
\text { Square }\end{array}$ & $\begin{array}{c}\text { F-value } \\
\text { (Significance } \\
\text { Level) }\end{array}$ \\
\hline Corrected Model & 164.667 & 7 & 23.524 & $\begin{array}{c}1.677 \\
(0.122) \\
\end{array}$ \\
\hline \multicolumn{5}{|l|}{ a. Main effects } \\
\hline gender $\left(X_{1}\right)$ & 0.300 & 1 & 0.300 & $\begin{array}{c}0.021 \\
(0.884)\end{array}$ \\
\hline family pattern $\left(\mathrm{X}_{2}\right)$ & 3.333 & 1 & 3.333 & $\begin{array}{c}0.238 \\
(0.627)\end{array}$ \\
\hline university type $\left(\mathrm{X}_{3}\right)$ & 128.133 & 1 & 128.133 & $\begin{array}{l}9.314 * \\
(0.003)\end{array}$ \\
\hline \multicolumn{5}{|l|}{ b. Interaction effects } \\
\hline $\begin{array}{l}\text { gender } \times \text { family pattern } \\
\left(X_{1} \times X_{2}\right)\end{array}$ & 0.300 & 1 & 0.300 & $\begin{array}{c}0.021 \\
(0.884)\end{array}$ \\
\hline $\begin{array}{l}\text { gender } \times \text { university type } \\
\left(X_{1} \times X_{3}\right)\end{array}$ & 17.633 & 1 & 17.633 & $\begin{array}{c}1.257 \\
(0.265)\end{array}$ \\
\hline $\begin{array}{l}\text { family pattern } \times \text { university } \\
\text { type }\left(\mathrm{X}_{2} \times \mathrm{X}_{3}\right)\end{array}$ & 13.333 & 1 & 13.333 & $\begin{array}{c}0.950 \\
(0.332)\end{array}$ \\
\hline $\begin{array}{l}\text { gender } \times \text { family pattern } \times \\
\text { university type }\left(X_{1} \times X_{2} \times X_{3}\right)\end{array}$ & 1.633 & 1 & 1.633 & $\begin{array}{c}0.116 \\
(0.734)\end{array}$ \\
\hline Error & 1571.20 & 112 & 14.029 & \\
\hline Total & 83064 & 120 & & \\
\hline Corrected Model & 1735.86 & 119 & & \\
\hline
\end{tabular}

An inspection of Table 2 shows that only one variable i.e. university type $\left(\mathrm{X}_{3}\right)$ has statistically significant effect on self-esteem $\left(\mathrm{Y}_{1}\right)$; other explanatory variables i.e. gender 
$\left(\mathrm{X}_{1}\right)$ and family-type $\left(\mathrm{X}_{2}\right)$ are not significant. In addition, there is no statistically significant interaction effect of the explanatory variables.

TABLE 3

UNDERGRADUATES OF THE UNIVERSITIES IN DHAKA: SUMMARY OF ANOVA OF SOCIAL RESPONSIBILITY SCORES (DEPENDANT VARIABLE) BY GENDER, FAMILY PATTERN AND UNIVERSITY TYPE

\begin{tabular}{|c|c|c|c|c|}
\hline Source & $\begin{array}{l}\text { Sum of } \\
\text { Squares }\end{array}$ & $\mathrm{df}$ & $\begin{array}{l}\text { Mean } \\
\text { Square }\end{array}$ & $\begin{array}{c}\text { F( Significance } \\
\text { level) }\end{array}$ \\
\hline Corrected Model & 419.700 & 7 & 59.957 & $\begin{array}{l}3.305^{*} \\
(0.003)\end{array}$ \\
\hline \multicolumn{5}{|l|}{ a. Main effects } \\
\hline gender $\left(X_{1}\right)$ & 17.633 & 1 & 17.633 & $\begin{array}{c}0.972 \\
(0.326)\end{array}$ \\
\hline family pattern $\left(\mathrm{X}_{2}\right)$ & 12.033 & 1 & 12.033 & $\begin{array}{c}0.663 \\
(0.417)\end{array}$ \\
\hline $\begin{array}{l}\text { university type } \\
\left(\mathrm{X}_{3}\right)\end{array}$ & 0.300 & 1 & 0.300 & $\begin{array}{c}0.017 \\
(0.898) \\
\end{array}$ \\
\hline \multicolumn{5}{|c|}{ b. Interaction effects } \\
\hline $\begin{array}{l}\text { gender } \times \text { family } \\
\text { pattern } \\
\left(\mathrm{X}_{1} \times \mathrm{X}_{2}\right)\end{array}$ & 61.633 & 1 & 61.633 & $\begin{array}{l}3.398 \\
(0.068)\end{array}$ \\
\hline $\begin{array}{l}\text { gender } \times \\
\text { university type } \\
\left(X_{1} \times X_{3}\right)\end{array}$ & 140.833 & 1 & 140.833 & $\begin{array}{l}7.764 * \\
(0.005)\end{array}$ \\
\hline $\begin{array}{l}\text { family } \times \text { university } \\
\text { type } \\
\left(\mathrm{X}_{2} \times \mathrm{X}_{3}\right)\end{array}$ & 9.633 & 1 & 9.633 & $\begin{array}{l}0.531 \\
(0.468)\end{array}$ \\
\hline $\begin{array}{l}\text { gender } \times \text { family } \\
\text { pattern } \times \\
\text { university type } \\
\left(\mathrm{X}_{1} \times \mathrm{X}_{2} \times \mathrm{X}_{3}\right)\end{array}$ & 177.633 & 1 & 177.633 & $\begin{array}{l}9.7938^{*} \\
(0.002)\end{array}$ \\
\hline Error & 2031.600 & 112 & 18.139 & \\
\hline Total & 105822.0 & 120 & & \\
\hline Corrected Total & 002451.3 & 119 & & \\
\hline
\end{tabular}

Notes: *shows statistically significant at least at one percent level.

** shows statistically significant at least at five percent level.

Table 3 deals with social responsibility as the dependent variable of gender $\left(\mathrm{X}_{1}\right)$, family-pattern $\left(\mathrm{X}_{2}\right)$ and university type $\left(\mathrm{X}_{3}\right)$; these variables (i.e., $\mathrm{X}_{1}, \mathrm{X}_{2}$, and $\left.X_{3}\right)$ are not significant. But the interaction effects of gender $\left(X_{1}\right)$ and university-type $\left(\mathrm{X}_{3}\right)$ and gender $\left(\mathrm{X}_{1}\right)$, family-pattern $\left(\mathrm{X}_{2}\right)$ and university-type $\left(\mathrm{X}_{3}\right)$ are significant. 
The results shown in Table 1 indicate that self-esteem of male and female undergraduates of Dhaka city differs from each other which is affirmed by the studies of a number of social psychologists where they have identified that the female children are always underestimated or undervalued by their grandparents, granduncles etc. in their rights, activities (Unger el.al., 1993; Resko, 1975). Though the modern female children are very much conscious and motivated to improve their continuous situation by acquiring better self-esteem, their continuous attempts are hindered because of our parenting style. Some other correlation studies have also showed that children tend to evaluate themselves in part on the basis of how they believe their parents evaluate them (Felson, 1989). Even it is found that if the parental attitudes and behaviour-acceptance to their children is clear and well-enforced for their actions within well-defined limits then it works as the primary antecedents of children's sense of self-worth which significantly influence (Pervin, 1993).

The reasons behind the possession of better self-esteem by the public university students than that of private ones $(\mathrm{CV}=0.142)$ are that the public university students generally come from the higher socio-economic status that provides them with some privileges and helps them to improve their self-esteem. Previous studies have indicated that self-esteem is lower among the adolescents of low socio-economic status and is associated with a number of intrapersonal, interpersonal and socio-cultural factors (Veselskaz, et al, 2009). This study has found that educational institutions influence to a great extent in the development of personality and mental health. It is also found that in the educational institutions the students are able to interact with the renowned personalities of the society as their teachers. As a matter of fact, it enhances their sense of worth and ultimately inspires them to be motivated.

\section{CONCLUSIONS}

The article emphasizes the significance of self-esteem and social responsibility in general and among the students of universities in particular. The study is based on the empirical evidences collected from a set of undergraduate students of Dhaka city. The study tries to analyze self-esteem and social responsibility by three explanatory variables of gender, family-pattern and university-type. The study shows that female students in general exude more selfesteem and social responsibility. When analyzed from the point of view of family-pattern, it is observed that students coming from joint-families are endowed with more self-esteem and social responsibility. Again, students of public universities possess higher level of self-esteem; it may be due to their higher level of socio-economic status. On the other hand, students of private universities exhibit higher degree of social responsibility. 


\section{REFERENCES}

Afrose, D. and Chowdhury, S. (1990): "Interpersonal Values of Males and Females of Two Generations". Dhaka University Journal of Psychology. Vol: 10; pp. 1015.

Andrews, F. M. and Withey, S. B. (1976): "Social Indicators of Well-being: American`s Perception of Life Quality". New York; Plenum Press.

Arvey, R.D.; Bouchard, T.J.; Segal, N.c. and Abraham, L.M.(1989): "Environment and Genetic Components", Journal of Applied Psychology, pp. 74, 187-192.

Bachman, J.G. and O’Mally, P.M.(1977): "Self-esteem in Young Men: A Longitudinal Analysis of the Impact of Education and Occupational Attainment". Journal of Press and Social Psychology. Vol: 6; pp. 365 -330.

Bear J.R. and Keller, L. (1994): "Psychological Correlates of Male \& Female Self-esteem in College Students: Is there a Stable Trait "Self-esteem?" Paper presented at the Sixth Annual Convention of the American Psychological Association". Washington D.C.

Begum, R. (1985): "Achievement Motivation of Boys and Girls Reared in Home and Institutional Environment". Dhaka University Journal of Psychology. Vol: 18; pp. 11-18.

Bell, P., A. Greence, T.C. Fisher, J.D and Baum A. (2001): Environmental Psychology. New York, Harcourt College Publishers.

Berkowitz, L. and Daniels, L.R. (1964): "Affecting the Salience of Social Responsibility Norm". Journal of Abnormal and Social Psychology; pp. 68, 275-281.

Berkowitz, L. and Lutterman, (1968): "The Traditional Socially Responsible Personally": The Public Opinion Quarterly. Pp. 32, 170-185.

Frone, M.R.; Russell, M. and Cooper, M.L. (1994): "Antecedents and Outcomes of work family conflict: Testing 0 Model of the Work Family Interface"; Journal of Applied Psychology; pp. 65-68.

Haque P. and Begum R. (1984): "Self-concept of High School Boys and Girls in Different Income Groups. Dhaka University Journal Psychology"; Vol. 14; pp. 57-64.

Homans, G.C. (1961): Social Behavior: Its Elementary Forms. New York: Harcourt, Brace and World.

Huq, M., Banu, S. and Mahmud, S.H. (1984): "Social Responsibility as a Function of Family Type, Social Group Membership and Urbanization". Dhaka University Journal of Psychology. Vol. 7; pp. 134-144.

Jahan, R. and Sarkaer, B.R. (1995): "Social Responsibility of Distressed People Residing in Urban and Rural Community in Bangladesh", Dhaka University Journal of Psychology. Vol. 19; pp. 1-19. 
Khanam, M. and Begum, R. (1997): "Social Responsibility of Women of Two Generations in Different Socio-economic Classes". Bangladesh Psychological Studies. Vol. 7; pp. 55-60.

McMullin, J.A. and Cairney, J. (2204): "Self-esteem and the Intersection of Age, Class and Gender. Journal of Aging Studies", Vol.18; pp. 75-95.

Schlenker, B.R.; Weingold, M.F. and Hallam, J.R. (1990): "Self-serving Attribution in Social Context: Effects of Self-esteem and Social Pressure". Journal of Personality and Social Psychology, pp. 855-863. 